\title{
An Analysis of Determinant Factors of Empowerment-Based Poverty Reduction
}

\author{
$1^{\text {st }}$ Rusni Djafar \\ Doctoral Student of Publik Administration \\ Universitas Negeri Makassar \\ rusnidjafar1966@gmail.com
}

\author{
$2^{\text {nd }}$ Husain Syam \\ Professor of Tekhnology Science, \\ Universitas Negeri Makassar \\ Husainsyam@gmail.com
}

\author{
$3^{\text {rd }}$ Rifdan \\ Professor of Public Adminstration \\ Universitas Negeri Makassar
}

\begin{abstract}
This research aims at analyzing and explaining the description of public services related to community empowerment-based poverty reduction. It also aims at analyzing the determinant factors of community empowerment-based poverty reduction in Pohuwato District. This research was a qualitative method with a case study approach. Data were collected using interview, documentation and direct observation. The data were analyzed through data reduction, data presentation, tentative conclusions and verification, data collection and final conclusions. These data analyzing were a cycle process or interactive process. The data were validated using the triangulation technique. This research shows that public services in community empowerment-based poverty reduction have not been optimal. Generally, lower level officials (sub-district and village) have not played an active role in communicating community development programs. The determinant factors of poverty reduction are ineffective communication, low resources, and behavior of government officials who have not been able to motivate and mobilize the community. The bureaucratic structure is still rigid, formal, inefficient and effective, which hinders the smoothness of public services and the successful implementation of poverty reduction programs. There is a government policy in communicating empowerment programs to the poor. The government provides adequate resources and serves a sincere and friendly manner without complicated bureaucratic procedures. Therefore, it is easy to access various community empowerment programs in Pohuwatu District.
\end{abstract}

Keywords - Determinants of poverty alleviation and Community Empowerment introduction

\section{INTRODUCTION}

Poverty is a problem that is generally faced in almost all developing countries, especially countries that are densely populated including Indonesia. That is why poverty reduction has always been a regime program that is powerful and attractive to be used as a scientific discourse.

Development is carried out to realize community prosperity through economic development. It is also to overcome various problems development and social community such as unemployment and poverty. Addition to economic growth, one important aspect to see performance development is how effective the use of resources is so that employment can absorb the available workforce. Increasing economic growth increased means that the productions of goods or services increase. Thus, more labor is required to produce goods or services so that unemployment and poverty decrease [1]-[5]. Poverty is a serious problem that still exists in Indonesia. Various efforts have been made starting from the regional, national and international scope. Some government policies on poverty are not yet able to reduce poverty. The poverty problems often arise along with the problem of unemployment. Both of these problems are closely related to the quality of human resources. For example, if someone is poor, he or she cannot go to higher school. The low education makes someone is limited to looking for workers' fields.

[6] reveals that the causes of poverty will lead to a theory that is a vicious cycle of poverty. The backwardness, market imperfections, and lack of capital cause low productivity. The low productivity causes low income. The low income will result in low savings. The low savings are also the low investment. If it continues without breaking the poverty chain, the current cycle continues to spin. Then one way is by improving the quality of human resources which acts as a driving motor economy of a region [7]-[10].

The government stipulates poverty reduction as one of the development priorities. The President of the Republic of Indonesia has issued Presidential Regulation Number 15 of 2010 concerning Acceleration of Poverty Reduction. The purpose of the issuance of this Presidential Regulation is to realize the vision and mission of the President who can reduce poverty to $8-10 \%$ by the end of 2014 . However, the scenario of achieving the Decrease in Poverty Rate until the end of the United Indonesia Cabinet Volume II ended in 2014 has not been able to touch the expected decline rate that is $8 \%-10 \%$.

In the last 5 (five) years until 2017 the percentage the number of poverty in Pohuwato, the poverty is still quite high and far from the national target as illustrated in the following table. 
TABLE 1. THE PERCENTAGE OF POHUWATO REGENCY'S POVERTY RATE IN THE LAST 5 (FIVE) YEARS AND NATIONAL TARGET

\begin{tabular}{|c|c|c|c|}
\hline No. & Year & \multicolumn{2}{|c|}{$\begin{array}{c}\text { Percentage of Regional Poverty } \\
\text { Rates and National Targets }\end{array}$} \\
\cline { 3 - 4 } & & $\begin{array}{c}\text { Pohuwato } \\
\text { District }\end{array}$ & $\begin{array}{c}\text { National } \\
\text { Target }\end{array}$ \\
\hline 1. & 2013 & $21.47 \%$ & $13.15 \%$ \\
\hline 2. & 2014 & $20.69 \%$ & $12.50 \%$ \\
\hline 3. & 2015 & $22.43 \%$ & $11.50 \%$ \\
\hline 4 & 2016 & $21.17 \%$ & $09.00 \%$ \\
\hline 5. & 2017 & $21.27 \%$ & $09.00 \%$ \\
\hline
\end{tabular}

Source Data: Processed from BPS data, 2017

The data in Table 1 illustrate that the percentage of poverty rates in Pohuwato Regency area is not yet showing a significant reduction. In 2013 the percentage of poverty was $21.47 \%$. It decreased as much as $2.42 \%$ from 2012 . However, it is still quite high compared to the national target that is $13.15 \%$. In 2014 , the percentage of poverty had decreased by as much as $0.78 \%$. It only increased in 2015 as much as $22.43 \%$, or $2.26 \%$. Meanwhile, in 2016, it was $21.17 \%$, and it was decreased as much as $1.26 \%$. However, in 2017 it increased as much as $1.00 \%$ that is $22.17 \%$.

The national poverty reduction rate which has not been achieved by Pohuwato District shows the development approach based on the target community has not been appropriately implemented. It is not realized that the problem of poverty is very complex, and it does not involve the poor themselves as program targets.

The poverty reduction programs from national to regional levels have tended to be partial and unsustainable. In addition, the role of the business world and society, in general, is not optimal. Meanwhile, social volunteerism in people's lives that can be a source of empowerment and the solution to the root causing poverty also begins to be faded. Poverty itself has not been seen as a tragic humanitarian disaster. As a global phenomenon that is very concerning, poverty must be resolved because it is a mandate of the constitution.

According to [11], to overcome poverty, improvements and changes in social structures need attention. It is because the structure of society has a culture that is reflected in the form of values and norms that lead to the behavior called the culture of poverty. The culture of poverty is an adaptation or adjustment and reaction of the poor to their marginal position in society.

Poverty is a common problem that must be tackled seriously. It is not a private matter, groups and even the government, but it is a problem for every Indonesian citizen. Concern and awareness among fellow citizens are expected to help in reducing poverty. [12] explains that it needs to change the pattern of governance from the concept of government to governance as a form of social-political interaction between the government and society in facing various problems which are complex, dynamic, and diverse [13].
In the concept of public administration, two things are emphasized. The first is how far or how much is the government's ability to overcome any public issues that arise. The second is that the scope of public administration concerns the actualization of the rights of the community through the implementation of every public policy made, where the public policy is a legal product that must be obeyed by citizens and the government [14].

The poverty reduction program requires a change in the dominant role of the government in the implementation of development towards the implementation and management of government. The government contains democratic, fair, transparent and distributive elements in managing resources and various problems faced by the community (governance).

Based on Presidential Decree number 54 in 2005, there are two main points that in to be realized in the poverty reduction program. The first is government management based on organized community participation. The second is the program is carried out with full openness with a healthy and accountable competitive climate. The implementation of regional government follows and puts forward the expectations and needs of the people proposed in a participatory-based on empowerment [15].

The results of the study show that poverty reduction programs are based on community empowerment in Pohuwato District. However, the programs have not described the synergy between the Regional Government and the private sector and the target community. Development of poverty reduction is still top-down. The governance perspective that is the reference for governance has not been implemented well, especially in synergizing the three pillars that become the power of community empowerment, namely, the government, the private sector, and the community. It is in line with the research findings of [16] in which their study showed that poverty reduction programs still use a top-down planning approach.

The development model that is used in meeting basic needs and the provision of facilities and infrastructure is indicated by the dominance of the regional government in implementing programs, especially poverty reduction programs originating from the central government. The role of the public tends to be passive so that the ability of the poor people to establish themselves independently and the environment is still very low.

[17] stated that development is a deliberate process to achieve better conditions. There are two development paradigms carried out so far namely the top-down paradigm and the bottom-up paradigm. A top-down paradigm is a form of blueprint strategy as a development paradigm that originates from the government. Therefore, the community is only a target or object of development. The bottom-up paradigm is a development paradigm that positions the community as a development center so that the community is involved in the planning process until implementation and evaluation [17].

A bottom-up paradigm is an ideal approach in development that is paying attention to initiative and 
creativity. It also accommodates the socio-cultural conditions of the local area, the potential and problems faced. Therefore, the development of the poor should have a sense of empowerment. [18] argues that the need for efforts to reduce the poor from the valley of poverty is through a strategy of finding relevant solutions to solve the problem by first looking for dominant factors (both cultural and structural) that cause poverty " [19].

[20] states that poor people have their habits that are different from most people. Negative attitudes such as laziness, fatalism or surrender to fate, feelings of worthlessness, helplessness, high dependence and a sense of inferiority do not have an entrepreneurial spirit and lack of respect for the work ethic. These kinds of attitudes will affect empowerment. Therefore, the socio-cultural values of the people and the people's economy are not well developed.

Community-based poverty reduction program is far from the nature of participation and independence because it does not touch the side of the fulfillment of basic needs as well as the development of inspiration and aspiration. Three aspects commonly known in community empowerment programs are assistance, facilitation, and promotion, and these aspects have not been appropriately implemented.

Poverty reduction programs must be performed entirely which means that it concerns all causes of poverty. Some of the implementations of programs need to be followed up and improved such as improving education and public health, expanding employment and cultivating entrepreneurship [21]-[24].

In addition, it has not been noted that the determinants of the success of poverty reduction include internal factors and external factors. Internal factors are related to the negative attitudes of the poor, as a result of several things. The first is the low quality of the resources they have. The second is the low quality of resources owned due to low levels of education. The external factors are related to the fate of the less fortunate and the existence of discrimination on the development policies applied.

Asserts that the thinking framework in the empowerment process contains at least three critical objectives. First, it is to create an atmosphere or climate that enables the potential of the community to develop. Second, it is to strengthen the potential or power of the community or group that will be empowered, for example through increasing the level of education, increasing health status, and increasing access to sources of progress. Third, it is to protect the competition which is not balanced, to establish justice, and to promote unity and partnership between the already advanced with undeveloped. Empowerment by emphasizing the three provisions above will obviously be a superior strategy and will have a positive impact on reducing poverty rates.

This study essentially describes the factors which determine the success of poverty reduction based on community empowerment in Pohuwat District. Therefore, the results of this study can contribute to poverty reduction based on community empowerment. Besides that, there is a need for commitment and concern in poverty reduction based on community empowerment. An effort to formulate new concepts of community empowerment in Pohuwato District, Gorontalo Province is required.

\section{RESEARCH METHODS}

This study applied descriptive qualitative research using a case study approach to reveal the meaning of empowermentbased poverty reduction cases in Pohuwato District. The study was carried out in Pohuwato District with by considering that Pohuwato Regency had a percentage of poverty above the national target that is $21.17 \%$.

This research is intended to analyze phenomena about empowerment-based poverty reduction systematically, factually and accurately. This research focuses on empowering the poor through assistance, facilitation and promotion activities. Empowerment of the poor through assistance activities is an activity in the form of training, consultation, and technical assistance, as well as similar activities which are synergically, leads to the provision of power or strength that makes the poor empowered and independent. Empowerment of the poor through facilitation activities is an activity in the form of synergistic facilities which allows the poor to have the ability to change themselves to be more productive and independent. Empowering the poor through promotional activities is empowering the poor by collaborating and synergizing with institutions or organizations (Government, Private, NGOs) to develop responsive services to create awareness, inform, persuade and influence the poor to be able to meet their needs in the fields that allow him to be independent.

The data were analyzed through data reduction, data presentation, drawing tentative conclusions and verification, data collection and drawing final conclusions. These analyzing processes were a process cycle or interactive process.

\section{RESULTS AND DISCUSSION}

This study analyzes empowerment-based poverty reduction and finding determinant factors for the success of poverty reduction in Pohuwato District.

The overview of the analysis of poverty in its implementation is still top-down. There is coordination by the related ministry and strong central government interference. It makes the role of local governments were not maximal up to the village level. It resulted in the goal of empowerment being neglected because facilitators who were appointed based on the Ministry of Social Affairs' decision as program assistants were more likely to prioritize administrative accountability rather than maximize the goal of empowering the poor. The public has not felt the weakness of the bureaucratic character that has been practiced so far. There is no a fundamental change felt by the poor in Pohuwato District.

Likewise, the management of training programs, consultation and technical assistance for the poor are still very centralistic including the assistance of other programs, 
both direct and indirect program. The implementation of programs that still has the nuances of the political system is practiced authoritatively. The poor are always in a marginal position, both programs that are direct or indirect and are managed by the community itself. The direct training activities are in two fields. The first is in the field of fisheries cultivation for fishers. The second is in the field of developing Small and Medium Enterprises (SMEs) in terms of business management and marketing training.

The indirect program is in the form of training in business development and quality building in the field of fisheries and utilization of agricultural products. The training programs are previously socialized to the target community. However, all of the activities from the planning to implementation are entirely based on the initiative and intervention of the Government through Local Government Unit and Village Government.

Based on the results of the interviews, this research shows that several determinant factors determine the empowerment of the poor in Pohuwato District. They are communication, resources, implementing dispositions and bureaucratic structures in service. These four factors become supporting factors if they are optimized. On the contrary, they will be an inhibiting factor if they are not optimized.

\section{A. Communication Factors}

Human life will always interact and communicate (including interpersonal communication) with others. Through interpersonal communication, there will always be face to face communication that is easier to deliver messages. The interpersonal communication in practice focuses on two points to build community or human resources. The first is providing information or advice to the upper and lower community. The second is building sustainability among people who are at the same level in a community.

The community empowerment in Pohuwotu District requires a specific learning process, and this process will not run without interpersonal communication between policymakers and the client which is prepared to be the selfreliant community. The contribution of interpersonal communication in community empowerment has the superior morality. The community will not be able to become an empowerment cadre that is needed by the community. This type of communication can run well and continuously. It can be said that policymakers in community empowerment will get satisfactory results by using the interpersonal communication.

The communication factors intended in this study is the communication between the apparatus and the beneficiaries of empowerment-based poverty reduction program. The ability to communicate with the authorities is essential to disseminate and transmit policy goals and targets of poverty reduction programs to groups or target households, in this case, the poor to reduce distortion. The objectives and targets of the program are not clear and even are not known at all by the target group. Therefore, there may be resistance or rejection from the target group. Similarly, the purpose of empowerment-based poverty reduction program needs to be transmitted or distributed to all the poor which become the targeted programs by government officials of the district, sub-district to village level.

\section{B. Resource Factor}

The resource factor intended in this study is the availability of resources both human resources as labor, as well as the supporting capacity of the smooth achievement of organizational goals in helping the success of empowermentbased poverty reduction. Apparatus as executors of government organizations, especially at the village level, is very decisive in achieving organizational goals. Such human resources should have a pleasant personality and have work skills that can support the successful implementation of the organization.

The quality of human resources is a decisive factor in community empowerment programs in alleviating poverty. The low quality of the apparatus indicates it in providing services. The bureaucracy is convoluted so that the effectiveness of community empowerment also experiences obstacles.

The existence of training activities programs, consultations, and technical assistance, as well as other similar activities, have not been coordinated with other supporting programs so that it is difficult for the facilitator to carry out assistance activities. The synergy between programs and stakeholders are expected to maximize activity. A rigorous budget administration accountability system hits it. Training activities, consultation and technical assistance, and similar activities that lead to the provision of power are not yet synergy with other activities that make the poor independent. These activities have not succeeded in building critical awareness. It has not been able to map potential and community needs.

The results show that leadership is the primary factor. The attention and policy of the Regent as the regional leader in the provision of infrastructure and facilities that can increase the capacity of the community is still supported by non-cash facilities in the form of National Health Insurance, Prosperous Family Card, Family Expectation Program, and provision of Rice for Poor Families. It is performed so that the poor are given various programs to improve their quality of life.

\section{Disposition and Attitude}

The attitude of the executor intended in this study is the attitude and behavior of the authorities in providing services to the community to assist the empowerment-based poverty reduction program.

Disposition is the character and characteristics possessed by the implementing apparatus. If the apparatus' attitude has a proper disposition, he or she will run the empowerment program well as desired by the rules that have been made. When the attitude of the authorities is different from the policy rules, the process of implementing the community empowerment program also becomes ineffective.

Program for empowering the poor requires an attitude of conduct that has desire and motivation. It also needs a responsible attitude to the poverty problem. The attitude 
itself is a reflection of the value a person has, and that value will have an impact on one's obedience, to be able to realize his duties as a government apparatus in Pohuwotu District.

Various development experiences show that the level of commitment and honesty of the apparatus is low. The slowness of poverty reduction programs in Pohuwotu District shows that there are attitudes or characteristics of officials that have not been optimal in empowering the poor.

\section{Ucracy Structure}

An essential aspect in the implementation of empowerment-based poverty reduction programs is the support of the local government based on the organizational structure for standard operating procedures. It becomes a guideline for every implementor in acting for the implementation of poverty reduction programs. Organizational structures that are too long will tend to soften supervision and cause red-type, namely complex bureaucratic procedures. In turn, it creates an inflexible organizational activity. The organizational structure which is needed in the implementation of empowerment -based poverty reduction programs is a structure that can coordinate various activities that involve cross-sectoral development.

Based on the analysis of determinant factors in empowerment-based poverty reduction, the design of empowerment-based poverty reduction program in Pohuwotu District can be illustrated in the following figure.

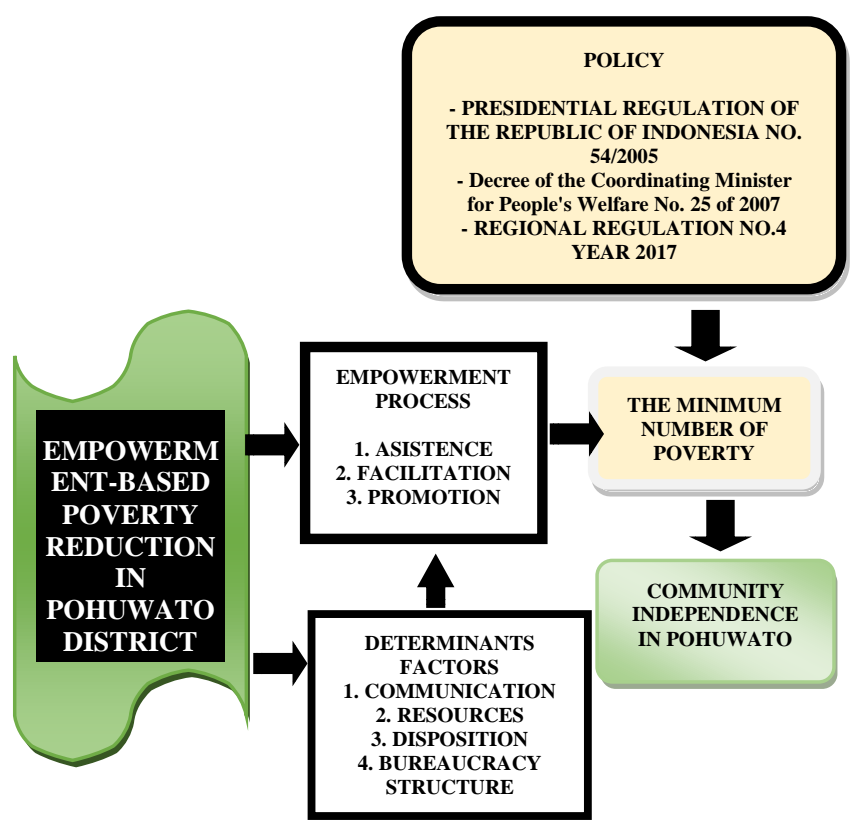

Fig.1. Schematic of the Determinant Factors of Empowerment-Based Poverty Reduction

Based on the analysis of the results of the study, the findings can be sorted according to the formulation of the problem, namely:

1. The main actors in the implementation of the empowerment-based poverty reduction program are played by implementers of government officials from the District, sub-District and Village levels, partnering with the private sector and stakeholders. The main actors must be established in a well-coordinated partnership collaboration mechanism to increase the synergy of interaction in assistance, facilitation and promotion activities.

2. Empowerment-based poverty reduction is sustainable depending on collaboration and coordination government, the private sector and stakeholders. It encourages interaction in assistance, facilitation, and promotion activities implementation of empowerment programs. In other words, the success of the empowerment-based poverty reduction depends on some factors namely collaboration and coordination of government, the private sector, and stakeholders. In the program, there is a synergistic interaction in the activities of assistance, facilitation and promotion implementation of empowerment programs.

3. The interaction that synergizes in assistance, facilitation and promotion activities on an ongoing basis in the implementation of empowerment programs is an intermediate variable from the latent variables of a partnership between the government, the private sector and stakeholders in increasing independence poor people.

Based on the analysis of research results as stated above, some propositions can be described in detail in order to recommend the prototype of a community empowermentbased poverty reduction model as follows:

1. The empowerment-based poverty reduction requires collaboration between the government, the private sector, and stakeholders who coordinate in the activities of assistance, facilitation and promotion sustainability. It means that the role of government which is synergized with the private sector and stakeholders in the activities of assistance, facilitation, and promotion creates the higher the self-reliance of the poor.

2. The empowerment-based poverty reduction requires communication, human resources, disposition and an adaptive bureaucratic structure. The more communicative community empowerment programs, more adequate resources are available. Moreover, the attitude of apparatus or officials in serving accompanied by the increasingly adaptive bureaucratic structure of the empowerment program organizers will be better. The independence of the community will also be higher.

\section{CONCLUSION}

Based on the results of this study, it can be concluded as follows;

1. The empowerment-based poverty reduction through assistance, facilitation and promotion activities in order to empower the poor in Pohuwato District has not maximally made the poor empowered and independent which is supported by training activities, consultation and technical assistance, and similar activities and collaborating through coordination of programs which makes it difficult for facilitators to conduct evaluation activities on these programs.

2. The determinant factors of the success of empowermentbased poverty reduction consist of five factors namely communication, resources, attitudes, and bureaucratic structures. These factors still become obstacles. 
Generally, lower level officials (sub-district and village) have not played an active role in communicating community development programs. Resources at the local level are less optimal. Therefore, empowermentbased poverty reduction programs have not met expectations. The attitude and behavior of government officials, especially at the local level, have not been able to motivate and mobilize the community in empowering themselves. The bureaucratic structure is still rigid, formal, inefficient and effective, which hinders the smooth running of public services and in turn hampers the success of program implementation.

\section{REFERENCES}

[1] R. M. Desai dan N. Rudra, "Trade, poverty, and social protection in developing countries," Eur. J. Polit. Econ., 2018.

[2] G. Siwach, "Unemployment shocks for individuals on the margin: Exploring recidivism effects," Labour Econ., vol. 52, hal. 231-244, 2018.

[3] A. Molnar et al., "Protocol: Realist synthesis of the impact of unemployment insurance policies on poverty and health," Eval. Program Plann., vol. 48, hal. 1-9, 2015.

[4] Z. Konečný, "Corporate Life Cycle as a Tool to Solve Technological Unemployment Just as to Lift Out of Poverty," Procedia - Soc. Behav. Sci., vol. 220, hal. 191-199, 2016.

[5] S. Emran dan F. Shilpi, "Agricultural Productivity, Hired Labor, Wages, and Poverty: Evidence from Bangladesh," World Dev., vol. 109, hal. 470-482, 2018 .

[6] M. Nisbett, "Empowering the empowered? Slum tourism and the depoliticization of poverty," Geoforum, vol. 85, hal. 37-45, 2017.

[7] V. Mani dan A. Gunasekaran, "Four forces of supply chain social sustainability adoption in emerging economies," Int. J. Prod. Econ., vol. 199, hal. 150-161, 2018.

[8] D. J. Soeder, "The successful development of gas and oil resources from shales in North America," J. Pet. Sci. Eng., vol. 163, hal. 399-420, 2018.

[9] R. Labra, J. A. Rock, dan I. Álvarez, "Identifying the key factors of growth in natural resource-driven countries. A look from the knowledge-based economy," Ensayos sobre Política Económica, vol. 34, no. 79, hal. 78-89, 2016.

[10] H.-L. Chang dan C.-Y. Lai, "Using travel socialization and underlying motivations to better understand motorcycle usage in Taiwan," Accid. Anal. Prev., vol. 79, hal. 212-220, 2015.

[11] S. Bouzarovski dan S. Petrova, "A global perspective on domestic energy deprivation: Overcoming the energy povertyfuel poverty binary," Energy Res. Soc. Sci., vol. 10, hal. 31-40, 2015.

[12] P. McLaverty, Public participation and innovations in community governance. Routledge, 2017.

[13] P. Miller dan N. Rose, "Political power beyond the state: Problematics of government," in Foucault and Law, Routledge, 2017, hal. 191-224.

[14] D. Fourie, "Financial control measures enhancing good governance," J. Public Adm., vol. 42, no. 7, hal. 733-743, 2007.

[15] S. Asiimwe dan G. M. Steyn, "Building Blocks to Effective and Sustainable University Governance in Uganda," J. Soc. Sci., vol. 39, no. 2, hal. 135-147, 2014

[16] T. Yulianto, "Fenomena Program-Program Pengentasan Kemiskinan Di Kabupaten Klaten (Studi Kasus Desa Jotangan Kecamatan Bayat)." Program Pasca Sarjana Universitas Diponegoro, 2005.

[17] M. Kuncoro, Otonomi \& pembangunan daerah. Erlangga, 2004.

[18] R. U. Khalid, S. Seuring, P. Beske, A. Land, S. A. Yawar, dan R. Wagner, "Putting sustainable supply chain management into base of the pyramid research," Supply Chain Manag. An Int. J., vol. 20, no. 6, hal. 681-696, 2015.

[19] R. A. Manners, Professional dominance: The social structure of medical care. Routledge, 2017.

[20] I. Mafruhah, Multidimensi kemiskinan. Kerja sama Lembaga Pengembangan Pendidikan (LPP) dan UPT Penerbitan dan
Pencetakan UNS (UNS Press), Universitas Sebelas Maret, 2009.

[21] Z. A. Rengifurwarin, A. H. Akib, U. N. M. Jasruddin, dan R. Salam, "Snapshot of Public Service Quality in The Center For Integrated Business Service (CIBS), Cooperative Micro Small and Medium Enterprises (CMSME), Maluku Province, Indonesia," J. Entrep. Educ., vol. 21, no. 3, 2018.

[22] A. Syam, H. Akib, M. Yunus, dan S. Hasbiah, "Determinants of entrepreneurship motivation for students at educational institution and education personnel in Indonesia.," J. Entrep. Educ., vol. 21, no. 2,2018

[23] M. Jufri, H. Akib, S. Ridjal, R. Sahabuddin, dan F. Said, "Improving Attitudes And Entrepreneurial Behaviour Of Students Based On Family Environment Factors At Vocational High School In Makassar," J. Entrep. Educ., vol. 21, no. 2, hal. 1-14, 2018.

[24] J. Papilaya, T. R. Soisa, dan H. Akib, "The Influence of Implementing the Strategic Policy in Creating Business Climate, Business Environment and Providing Support Facilities towards Business Empowerment on Small Medium Craft enterprises in Ambon Indonesia," Int. Rev. Manag. Mark., vol. 5, no. 2, hal. 85-93, 2015. 